\title{
Size Composition of Fish By-Catch Species from Industrial Shrimp Trawl Fishery in Nigerian Coastal Waters
}

\author{
I.O. Taiwo ${ }^{1^{*}}$ and O.A Olopade ${ }^{2}$ \\ 1Institute of Food Security, Environmental Resources and Agricultural Research, Federal University of Agriculture, \\ PMB 2240, Abeokuta, Nigeria \\ 2Department of Fisheries, University of Port-Harcourt, Nigeria \\ Email: iomtai@yahoo.com
}

\begin{abstract}
Fish species composition of by-catch in the industrial shrimp trawl fishery in Nigeria was investigated with the Sciaenidae family being the most prevalent by-catch fish species. In order of prevalence Pseudolithus elongatus with a mean weight and length of $15.28 \mathrm{~g}$ and $86.39 \mathrm{~mm}$, respectively and Pseudolithus typus $(n=102)$ having an average weight of $18.76 \mathrm{~g}$ and mean length of $88.01 \mathrm{~mm}$. Other fish by-catch species include Pseudolithus senegalensis $(n=99$, mean weigh $=15.49 \mathrm{~g}$, mean length $=88.60 \mathrm{~mm})$; Galeoides decadactylus $(n=59$, mean weight $=15.26 \mathrm{~g}$, mean length $=87.66 \mathrm{~mm})$; Pteroscion peli $(n=48$, mean weight $=16.05 \mathrm{~g}$, mean length $=$ $88.23 \mathrm{~mm})$; Drepane africana $(n=33$, mean weight $=13.29 \mathrm{~g}$, mean length $=45.73 \mathrm{~mm})$ and Cynoglossus senegalensis $(n=11$, mean weight $=21.78 \mathrm{~g}$, mean length $=86.45 \mathrm{~mm})$. Despite the small number of Cynoglossus senegalensis, it had the highest weight contribution to the by-catch. Significant $(P<0.01)$ relationship exists between weight and length of fish species. The adjusted $R^{2}$ of the parameters indicated that $19.4 \%$ of the weight gained is accounted for by increase in length of Pseudolithus elongatus; $1.7 \%$ in Pseudolithus typus; $31.7 \%$ in Pseudolithus senegalensis; $13.7 \%$ in Galeoides decadactylus; $7.8 \%$ in Pteroscion peli; $57.4 \%$ in Drepane Africana; and 48.9\% in Cynoglossus senegalensis. The by-catch associated with shrimp trawls should be properly monitored and controlled to reduce the quantity of non-target fish species in their catch. Also, the use of diamond-shaped $44 \mathrm{~mm}$ mesh size for shrimp should be encouraged or made mandatory for fishers to reduce fish by-catch.
\end{abstract}

Keywords: Shrimp, by-catch, fishery, weight

\section{Introduction}

Shrimp is a very high value seafood product, accounting for $20 \%$ of the total value of internationally traded fishery products (FAO, 2012). The Penaeid shrimps found in the Nigerian coastal waters include Penaeus notialis (Pink shrimp), $P$. kerathurus (Zebra shrimp), Parapenaeopsis atlantica (Brown Shrimp), Penaeopsis miersi. Others are Aristeus varidens, Plesiopenaeus edwardsianus and Parapenaeus longirostris (Red shrimp). The Pink shrimp, $P$. notialis dominates the shrimp fishery because it is the most abundant and commercial species often consisting as much as $90 \%$ of the shrimps' landing (Adetayo, 1984). Marine shrimp resources in Nigeria are exploited by industrial and artisanal fisheries, with the former being a limited entry fishery (FDF, 2000); in which about 266 otterboard trawlers are licensed to catch principally pink shrimp, Penaeus notialis in inshore and offshore waters for export (FDF, 1).

The shrimp production in Nigeria has a great demand potential in both local and international markets. It is export-oriented with Japan, U.S.A, and Britain being the main importers (Adetayo, 1984). However, the shrimp fisheries have been presently characterized by high percentage fish by-catch which consists of large quantities of unmarketable juvenile fish. These include Brachydeuterus auritus, Galieodes decadactylus, Illisha africana and, Pseudolithus sp. Thus making shrimp trawling less profitable and a seriously threat to fish stock population and the ecosystem at large (Adetayo, 1984).

This by-catch is either thrown back to sea, where likelihood of survival can be low (Hall et al. 2000) or, if of adequate commercial value, kept and landed. Bycatch levels vary among fisheries in quantity and species caught (Revill, 2003). By-catch to shrimp ratios varies according to the fishery can be as high as $40: 1$, as recorded by a study carried out on the Venezuelan Shrimp fishery (FDF,2000). Other by-catch to shrimp ratios are found in Indonesia (26:1) (FAO, 2001) and Australia (21:1) (Salini, 2000). On average, it is estimated that shrimp trawling produces by-catch to shrimp ratio of 
5:1 in the temperate and sub-tropical waters, and 10:1 in tropical waters (Ye et al., 2000). Yet, as the previous figures indicate, these can often be much higher. High by-catch rates are partly linked with the nature of demersal trawling: large numbers of fish (and other organisms) congregate on or just above the seabed. Queensland's East Coast trawl fishery (Australia) is estimated to have caught a minimum of $750 \mathrm{~kg}$ of by-catch per boat per day, with an annual total of $56,486,250 \mathrm{~kg}$ or 56,000 tonnes (WWF, 2002).

Industrial shrimp trawling in tropical waters is a leading offender in the capture of by-catch and accounts for about $27 \%$ of all global discards. In 1994, by-catch from shrimp trawl was estimated to be around 11.2 million tonnes worldwide (Alverson, et al., 1994). By-catch in shrimp trawls and associated discards is an issue affecting the sustainability of marine capture fisheries (Hall, 2000). Shrimp trawling is generally regarded as one of the least selective fishing methods because the by-catch may contain over hundreds of teleost species and outweigh the shrimp catch by 20 to 1 or more (Eayrs, 2007).

Global data on by-catch indicate that tremendous quantities of marine life are being removed. For many of the species incidentally caught in shrimp trawl nets, there is very little information (and sometimes none at all) from which to evaluate the sustainability of their mortality (Poiner et al., 1998). Because tropical seas are multispecies fishery, this has made shrimp trawling in the tropics especially harmful in terms of its effects on biodiversity. By-catch in tropical shrimp fisheries can comprise hundreds of species For example a recent report indicated that 437 vertebrate species (e.g. fish, sharks, rays) and 234 invertebrate taxa (e.g. crabs, squids and scallops) are incidentally caught in Australia's Northern Prawn Fishery (Stobutzki, 2001). Furthermore, as a much larger part of the world's shrimp production originates from the tropics, the total by-catch from this area is higher (FAO, 2001).

In many tropical countries, the trawlers come very close to shore in search of shrimp (Adetayo, 1984). These nearshore habitats often act as nursery areas for juveniles or many fish species. Therefore, they contain millions of young fish that are necessary to maintain adult populations. When vessels trawl in these nursery grounds, large numbers of juvenile fish are caught. Sustained nearshore trawling and subsequent mortality of juveniles is thought to affect many fish populations, particularly those of commercial importance (Broadhurst, 2000; Rahman, 2001).
The study therefore seeks to investigate the number of fish by-catch species in the industrial shrimp-trawl fishery of Nigeria and the length and weight relationship of these by-catch species.

\section{Materials and Methods}

The study site was the Lagos port where the shrimp trawlers land their catch from sea. These trawlers do not have by-catch excluding devises and the mesh size in use was not the size (cod-end mesh size of $44 \mathrm{~mm}$ ) recommended for shrimp trawling. Data on quantity and composition of by-catch fish species and their physical parameters (length and weight measurement) was taken from randomly selected shrimp trawlers. The data were collected directly from the fishing companies for accuracy of catch composition between January and September, 2016.

The by-catch fish species were identified individually with the assistance of keys (Schneider, 1990). All measurements of length (L) and body weight (BW) were taken to the nearest $0.1 \mathrm{~cm}$ and $0.1 \mathrm{~g}$ respectively. The data collected was analyzed using frequency table, means and percentages. Correlation coefficient ( $r$ ) was also used to determine the relationship between weight and length of the by-catch fish species while regression analysis was used to analyze the weight and length differentials of fish species caught as by-catch in the shrimp trawl fishery.

\section{Results and Discussion}

In this study, 461 fishes belonging to seven fish species from five families were observed as bycatch landed in the shrimp trawl fishery. The most prevalent family was Sciaenidae with three species. The remaining four families were represented only by one species each (Table 1.). The most prevalent by-catch fish species was Pseudolithus elongatus ( $\mathrm{n}$ $=109$ ) with a mean weight of $15.28 \mathrm{~g}$ and mean length of $86.39 \mathrm{~mm}$ (Table 2). This was followed by Pseudolithus typus $(n=102)$ with an average weight of $18.76 \mathrm{~g}$ and mean length of $88.01 \mathrm{~mm}$. Other bycatch fish species included: Pseudolithus senegalensis $(n=99$, mean weight $=15.49 \mathrm{~g}$, mean length $=88.60 \mathrm{~mm})$; Galeoides decadactylus $(n=59$, mean weight $=15.26 \mathrm{~g}$, mean length $=87.66 \mathrm{~mm})$; Pteroscion peli $(\mathrm{n}=48$, mean weight $=16.05 \mathrm{~g}$, mean length $=88.23 \mathrm{~mm})$; Drepane africana $(n=33$, mean weight=13.29g, mean length $=45.73 \mathrm{~mm}$ ) and Cynoglossus senegalensis $(n=11$, mean weight $=$ $21.78 \mathrm{~g}$, mean length $=86.45 \mathrm{~mm}$ ). Although, Cynoglossus senegalensis was the least in terms of number caught, it contributed the greatest weight of 
the by-catch. This indicated that the bulk of the bycatch fish species juveniles of commercially important fish species. (FAO, 2001) had similar findings in a survey which was conducted between December 1998 and March 1999 in which 70\% of the by-catch comprised juveniles of commercially important species with a maximum length at infinity not exceeding $35 \mathrm{~mm}$.

The relationships between the weight and length of the by-catch fish species significant at the 0.01 level of significance $(P<0.01)$ except for Pteroscion peli $(r=0.313, P<0.05)$ that is significant at the 0.05 level of significance (Table 3.). This indicates that as the length of fish increases weight increases and vice-versa giving a straight line when weight is plotted against length.
There were significant $(P<0.01)$ differences between the weight gained length increases between the by-catch fish species (Table 4.). Thus a $19.4 \%$ increase in weight results in an increase in length in Pseudolithus elongatus, $1.7 \%$ in Pseudolithus typus, $31.7 \%$ in Pseudolithus senegalensis, $13.7 \%$ in Galeoides decadactylus, $7.8 \%$ in Pteroscion peli, $57.4 \%$ in Drepane africana, and $48.9 \%$ in Cynoglossus senegalensis. This indicates the rate of growth of the by-catch fish species with a growth rate of Pseudolithus typus in relation to weight the least.

FAO (2001) noted the high number of bycatch in the Nigeria shrimp trawl fishery which corroborates this study. However, stated that the exact number of by-catch and discards are not

Table 1. By-Catch Composition in the Shrimp Trawl Fishery

\begin{tabular}{|c|c|c|c|c|}
\hline Family & Scientific name & Common name & Number & Percentage (\%) \\
\hline \multirow{4}{*}{ Sciaenidae } & Pseudolithus elongatus & Short croaker & 109 & 23.64 \\
\hline & Pseudolithus typus & Long neck croaker & 102 & 22.13 \\
\hline & Pseudolithus senegalensis & Cassava croaker & 99 & 21.48 \\
\hline & Pteroscion peli & Boe drum & 48 & 10.41 \\
\hline Polynemidae & Galeoides decadactylus & Shiny nose & 59 & 12.80 \\
\hline Drepaneidae & Drepane africana & Spade fish & 33 & 7.16 \\
\hline Cynoglossidae & Cynoglossus senegalensis & Sole fish & 11 & 2.39 \\
\hline Total & & & 461 & 100 \\
\hline
\end{tabular}

Table 2. Weights and Lengths of By-Catch Fish species

\begin{tabular}{|c|c|c|c|c|c|c|}
\hline Fish Species & $\mathrm{N}$ & Mean weights & Standard dev. & Weight variance & Min. weight & Max. weight \\
\hline Pseudolithus elongatus & 109 & 15.2807 & 0.4719 & 0.2270 & 14.50 & 16.00 \\
\hline Pseudolithus typus & 102 & 18.7647 & 0.4496 & 0.2021 & 17.60 & 19.60 \\
\hline Pseudolithus senegalensis & 99 & 15.4899 & 0.3406 & 0.1160 & 15.00 & 16.00 \\
\hline Galeoides decadactylus & 59 & 15.2593 & 0.7325 & 0.5366 & 14.00 & 16.90 \\
\hline Pteroscion peli & 48 & 16.0500 & 0.6175 & 0.3813 & 15.00 & 17.00 \\
\hline Drepane africana & 33 & 13.2879 & 0.7175 & 0.5148 & 12.00 & 14.30 \\
\hline Cynoglossus senegalensis & 11 & 21.7818 & 2.6525 & 7.0356 & 18.00 & 25.50 \\
\hline Fish Species & $\mathrm{N}$ & Mean length & Standard dev. & Length variance & Min. length & Max. length \\
\hline Pseudolithus elongatus & 109 & 86.3853 & 4.0389 & 16.3131 & 80.00 & 95.00 \\
\hline Pseudolithus typus & 102 & 88.0098 & 4.0459 & 16.2078 & 80.00 & 95.00 \\
\hline Pseudolithus senegalensis & 99 & 88.5960 & 3.5911 & 12.8936 & 81.00 & 95.00 \\
\hline Galeoides decadactylus & 59 & 87.6610 & 4.6484 & 21.6072 & 80.00 & 95.00 \\
\hline Pteroscion peli & 48 & 88.2292 & 3.0683 & 9.4145 & 81.00 & 94.00 \\
\hline Drepane africana & 33 & 45.7273 & 3.6252 & 13.1420 & 40.00 & 51.00 \\
\hline Cynoglossus senegalensis & 11 & 86.4545 & 13.7504 & 189.0727 & 65.00 & 110.00 \\
\hline
\end{tabular}

Table 3. Correlation analysis of the weights and lengths of the by-catch fish species

\begin{tabular}{lllll}
\hline \multicolumn{1}{c}{ Fish Species } & $\mathrm{N}$ & r value & $\mathrm{p}$ value & p level \\
\hline Pseudolithus elongatus & 109 & $0.449^{* *}$ & 0.000 & 0.010 \\
Pseudolithus typus & 102 & $0.167^{* *}$ & 0.099 & 0.010 \\
Pseudolithus senegalensis & 99 & $0.569 * *$ & 0.000 & 0.010 \\
Galeoides decadactylus & 59 & $0.390^{* *}$ & 0.002 & 0.010 \\
Pteroscion peli & 48 & $0.313^{*}$ & 0.030 & 0.050 \\
Drepane africana & 33 & $0.716^{* *}$ & 0.000 & 0.010 \\
Cynoglossus senegalensis & 11 & $0.735^{* *}$ & 0.010 & 0.010 \\
\hline
\end{tabular}


Table 4. Regression analysis of the weights and lengths differentials of the by-catch fish species

\begin{tabular}{|c|c|c|c|c|c|c|}
\hline Fish Species & Constant & Estimates & $\mathrm{R}^{2}$ & Adj $R^{2}$ & F value & $P$ value \\
\hline Pseudolithus elongatus & $27.670(11.303)$ & $3.842(0.739)$ & 0.202 & 0.194 & 27.008 & 0.000 \\
\hline Pseudolithus typus & $62.686(15.44)$ & $1.371(0.823)$ & 0.026 & 0.017 & 2.776 & 0.099 \\
\hline Pseudolithus senegalensis & $-4.312(13.64)$ & $5.998(0.880)$ & 0.324 & 0.317 & 46.416 & 0.000 \\
\hline Galeoides decadactylus & 49.915 (11.824) & $2.474(0.774)$ & 0.152 & 0.137 & 10.214 & 0.000 \\
\hline Pteroscion peli & $63.285(11.177)$ & $1.554(0.696)$ & 0.098 & 0.078 & 4.988 & 0.030 \\
\hline Drepane africana & $-5.723(7.757))$ & $3.872(0.583)$ & 0.587 & 0.574 & 44.119 & 0.000 \\
\hline Cynoglossus senegalensis & $3.456(25.691)$ & $3.810(1.172)$ & 0.540 & 0.489 & 10.578 & 0.010 \\
\hline
\end{tabular}

known. The study indicated that the bulk of by-catch fish species were commercially important species which are taken before they can mature to reproduce. This development is thereby making shrimp trawling less profitable and seriously affect the population of fish stocks and the ecosystem at large (Adetayo, 1984).

\section{Conclusion}

The study indicated that the bulk of by-catch fish species were commercially important species which are taken before they can mature to reproduce. This is affecting the size of these commercially important fish species offered for sale in markets. The fish by-catch of target species and incidental catches of non-target species was found to be of considerable quantity.

Fish by-catch in the shrimp trawl fishery is a threat to food security and sustainable fish production. It is advisable that the cod end mesh size of $44 \mathrm{~mm}$ mesh for catching shrimps should be enforced. Shrimping should not be allowed at closed areas, which are the spawning and nursery grounds for these commercially important fish species. Bycatch excluding devices should be introduced to allow juvenile or undersized fish to escape capture.

\section{References}

Adetayo, J.A. 1984. The recent trends and future prospects of the Nigerian shrimp fishery, NIOMR technical Paper publication pp3.

Alverson, D.L., Feeberg, M.H., Murawski, S.A. \& Pope, J.A. 1994. By-catch and Discards in World Fisheries: Quantities, Impacts and Philosophical Bases for their Management. FAO Fisheries Technical Paper 339, 233p.

Broadhurst, M. 2000. Modification to reduce bycatch in prawn trawls. A review and framework for development. Rev. Fish Biol. Fisheries. 10: 27-60.
Eayrs, S. 2007. A guide to the By-catch Reduction in Tropical Shrimp - Trawl Fisheries Revised Edition. Food and Agriculture Organisation of the United Nations (FAO) Rome.108pp.

FAO. 2001. Tropical shrimp fisheries and their impact on living resources. Shrimp fisheries in Asia: Bangladesh, Indonesia and the Philippines; in the Near East: Bahrain and Iran; in Africa: Cameroon, Nigeria and the United Republic of Tanzania; in Latin America: Colombia, Costa Rica, Cuba, Trinidad and Tobago, and Venezuela FAO Fisheries Circular. No. 974. Rome, FAO. 378p.

FAO. 2012. The State of World Fisheries and Aquaculture (SOFIA) 2012 Food and Agricultural Organization of the United Nations, Rome, Italy 230pp.

Federal Department of Fisheries (FDF). 2000. Federal Department of Fisheries Report.

Hall, M.A., Alverson, D.L. \& Metrzals, K.I. 2000. Bycatch: problems and solution Seas of the millennium an environmental evaluation Vol III Global issue and processes (ed. CR Sheppard) pp 135 - 151.

Poiner, I., Glaister, J., Pitcher, R., Burridge, C., Wassenberg, T., Gribble, N., Hill, B., Blaber, S., Milton, D., Brewer, D. \& Ellis, N. 1998. The environmental effects of prawn trawling in the far northern section of the Great Barrier Reef Marine Park: 1991- 1996. Final Report to the Great Barrier Reef Marine Park Authority and the Fisheries Research and Development Corporation.

Rahman, M. 2001. The impact of shrimp trawling fisheries on living marine resources of Bangladesh. Tropical shrimp fisheries and their impacts on living resources. Food and Agriculture Organization of the United Nations, Rome.

Revill, A. 2003. A study on the consequences of technological innovation in the capture fishing 
industry and the likely effects upon environmental impacts. CEFAS series: Technological Advancement \& The Environmental Impacts of Capture Fisheries. Royal Commission on Environmental Pollution, UK.

Salini, J. 2000. Assessment and benefits of damage reduction in prawns due to use of different bycatch reduction devices in the Gulf of Carpentaria, Australia. Fisheries Res. 45: 1-8.

Schneider, W. 1990. FAO Species identification sheet for fishery purposes. Field guide to the commercial marine resources of the Gulf of
Guinea. FAO Regional office for Africa. Rome. FAO 1990. 268 p.

Stobutzki, I. 2001. By-catch diversity and variation in tropical Australian penaeid fishery: the implications for monitoring. Fisheries Res. 53: 283-301.

Ye, Y., Alsaffar, A.H. \& Mohammed, H.M.A. 2000. Bycatch and discards of the Kuwait shrimp fishery. Fisheries Res. 45:9-19.

WWF Australia. 2002. Scrapping the bottom: seafloor trawling in the Great Barrier Reef World Heritage Area, WWF Australia, Sydney. 